\title{
Book review: Higher Education Strategy and Planning: A professional guide, edited by Tony Strike
}

Paul Temple (iD)

\section{How to cite this article}

Temple, P. (2020) 'Book review: Higher Education Strategy and Planning: A professional guide, edited by Tony Strike'. London Review of Education, 18 (1): 148-150. https://doi.org/10.18546/LRE.18.1.12

Submission date: 24 September 2018

Acceptance date: 25 September 2018

Publication date: 1 March 2020

\section{Peer review}

This article has been through editorial review.

\section{Copyright}

(C) Copyright 2020 Temple. This is an Open Access article distributed under the terms of the Creative Commons Attribution Licence (CC BY) 4.0 https://creativecommons.org/licenses/by/4.0/, which permits unrestricted use, distribution and reproduction in any medium, provided the original author and source are credited.

\section{Open access}

London Review of Education is a peer-reviewed open-access journal. 


\section{Book review}

Paul Temple* - UCL Institute of Education, UK

Higher Education Strategy and Planning: A professional guide, edited by Tony Strike

Abingdon: Routledge; 2018; 257 pp.; ISBNs: 978-1-13863-526-5 (pbk);

978-1-13863-521-0 (hbk); 978-1-31520-645-5 (ebk)

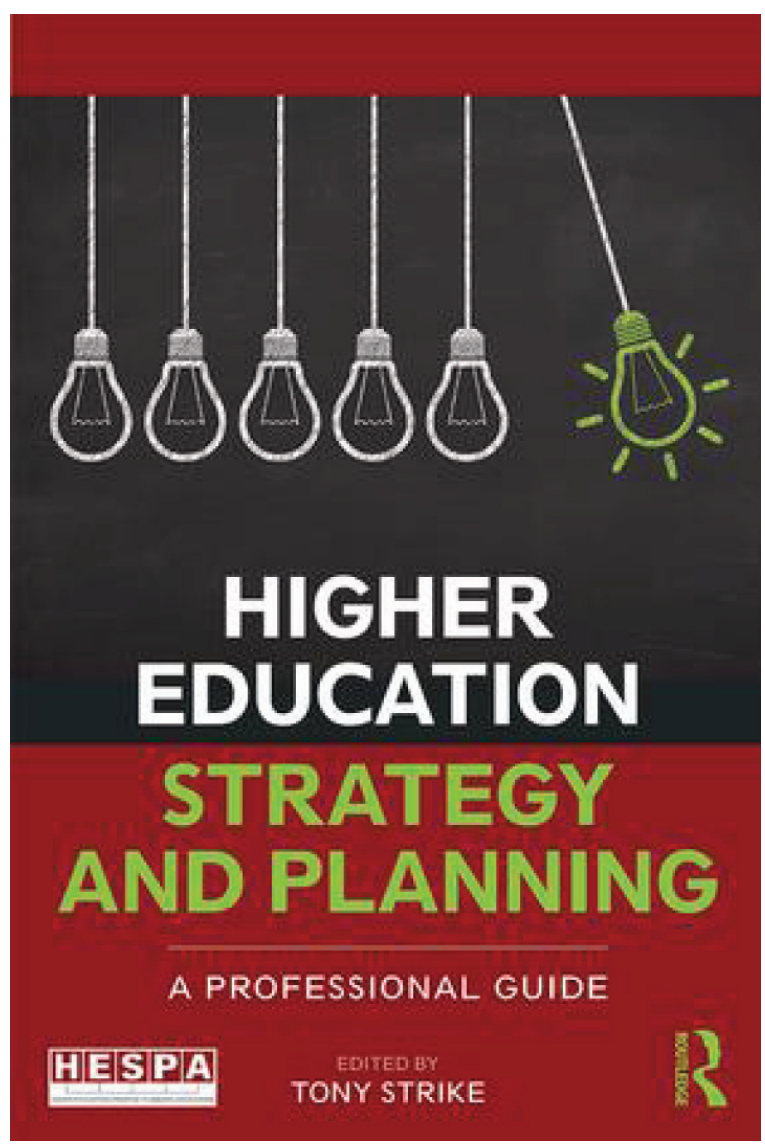

The strategic planning function in higher education is a little strange, considering that its intended main output is the institutional strategy. The simple question to be asked in retrospect of any strategy - military, business, health, anything - is, did it work? Did you win the war? Did your profits go up? Did you beat the disease? Business school textbooks usually give case studies of firms' strategic successes, perhaps by coming up with brilliant new products (Apple), or a new service that becomes hugely popular (Uber), while also pointing to strategic failures: the disastrous Australian takeover of the UK Homebase retail chain will be a business school seminar topic for years to come. So why is it apparently so difficult - and this book is not alone in this - to be able to point to a particular university's strategy and say, 'Look, this is what they did that was 
special, and here's the evidence that it worked (or not)'. If you cannot do this, what is the point of university strategic planning?

It was unlucky timing that the one specific case of strategy formulation given in this book shows how the UK's Open University went about it. John Pritchard's chapter on 'Developing institutional strategy' shows its vice chancellor playing a key role in the process, 'with care taken to actively engage multiple stakeholders at each stage' (61). Unfortunately, the book's publication coincided with the vice chancellor's resignation, having lost the confidence of his governing body and the academic senate, who seemed to feel that cutting courses and jobs in response to poor student recruitment and retention was not their idea of a strategy. The stakeholder engagement apparently was not quite 'active' enough. Certainly, the Open University badly needs a new strategy to escape from its present troubles, and 'encourag[ing] colleagues to reevaluate their assumptions and think more deeply and systematically about the challenges facing the institution' (52) would probably be a good start. The problem is that, as Mintzberg (1994) argues, more analysis - which is largely what is on offer in this chapter ('define work streams', 'determine priorities' and so on) - cannot lead to a new strategic synthesis. There seems to be a step missing between the strategic aim of re-evaluating assumptions and so on, and the largely routine analytical tasks actually proposed.

George Keller's Academic Strategy (1983) was one of the first books to propose that aspects of university management could be conceptualized in terms of institutional strategy. Keller's book became influential in America, the UK and elsewhere: Celia Whitchurch and I were quick to borrow some of his ideas for our book Strategic Choice (Temple and Whitchurch, 1989). Keller's clever research method was to identify universities that had recently been struggling, but which now seemed to be on track to recovery - so a sort of longitudinal study, looking back and comparing then with now. As the usual turn-around technique involved firing the university's president, the new person at the top was happy to tell Keller about the mess they had inherited, and how they had moved to sort it out. (The Open University's vice chancellor might profitably have read Keller as a warning.) As a result, a strength of Keller's book is that his cases involve named individuals, in particular universities, making the decisions that Keller chooses to label 'strategic'. His book describes specific changes, and notes the results.

The present book does not do these things, but instead mainly confines itself to generalities, which unfortunately often do not take us very far in understanding the character of strategic change, and how it may be brought about. This is despite Tony Strike's observation in his introduction, which Keller would have approved of, that 'strategic planners ... have to respond to this new [market-based] orthodoxy, while holding true to their institutions' missions, values and identities' (6). An example of this tension being handled in practice would have been valuable, rather than (again in Pritchard's chapter) having it explained that 'Strategy development is primarily about thinking strategically' (52). The chapter by Boggan, Lambert, Westlake and Wykes on 'Generating a research strategy' addresses a matter that most university planners will have found tricky, and starts promisingly by admitting that the risk is that planning here will just become 'bureaucratic meddling' (113) with academics' own plans. The solution? 'tough decisions' to create a strategy that is 'distinctive and authentic' (114). This chapter positively cries out for a Keller-type case study, showing how the 'picking winners' approach - which (I think) the authors are recommending - has worked out in practice. (I understand that the chapter authors in this book were asked to describe processes rather than report on outcomes, but linking the two would surely have produced valuable findings for practitioners and theoreticians alike.) 
It is a pity that none of the writers here seem to have reflected on Robert Birnbaum's perceptive and entertaining book on university strategic planning, and much else, Management Fads in Higher Education (2001). For Birnbaum, strategic planning is a classic fad in that it seems at first sight to be so eminently reasonable, and to settle so many internal decisions: who could possibly object to the aim, as Chadwick and Kew-Fickus put it in their chapter, of 'balanc[ing] institutional with departmental needs and visions, short-term efficacy with long-term sustainability and resources with reputation ... [strategies] identify a direction and goals, and also a means of getting there' (71). Birnbaum's objection is not to these desirable aims, but to the ways in which the processes that the chapters in this book describe get in the way of more useful organizational activities, lead to various internal dysfunctions (which he describes), and - above all - do not (cannot, Birnbaum insists) deliver on their grand promises. It would have been good to hear from the authors here why they believe themselves to be exempt from Birnbaum's critique. Perhaps the Open University's ex-vice chancellor is currently reflecting on this very point.

\section{References}

Birnbaum, R. (2001) Management Fads in Higher Education: Where they come from, what they do, why they fail. San Francisco: Jossey-Bass.

Keller, G. (1983) Academic Strategy: The management revolution in American higher education. Baltimore: The Johns Hopkins University Press.

Mintzberg, H. (1994) The Rise and Fall of Strategic Planning. New York: Prentice Hall.

Temple, P. and Whitchurch, C. (eds) (1989) Strategic Choice: Corporate strategies for change in higher education. Reading: Conference of University Administrators. 